\title{
Intravenous Iron Isomaltoside 1000 Reduces Postoperative Anemia in Patients Undergoing Elective Urologic Surgery and Those with Urosepsis
}

Drug Design, Development and Therapy

\author{
Hyeok Jun Goh $\mathbb{I D}^{1}$ \\ Ki Soo Lee (D) \\ Tae Hyo Kim' \\ Kyu Nam Kim² \\ Hyun Jin Lim $^{2}$ \\ Kyu Shik Kim ${ }^{3}$ \\ Won Jae Yang ${ }^{4}$ \\ Jung $\mathrm{Ki}$ Jo (iD ${ }^{3}$
}

'Department of Urology, Dong-A University, College of Medicine, Busan, Korea; ${ }^{2}$ Department of Anesthesia and Pain Medicine, Hanyang University, College of Medicine, Seoul, Korea; ${ }^{3}$ Department of Urology, Hanyang University, College of Medicine, Seoul, Korea; ${ }^{4}$ Department of Urology, Soonchunghyang University Hospital, Seoul, Korea
Correspondence: Jung Ki Jo Department of Urology, Hanyang University, College of Medicine, 222-I

Wangsimni-ro, Seongdong-gu, Seoul

04763, Korea

Tel +821025I9624I

Email victorjo38@hanyang.ac.kr

\begin{abstract}
Purpose: Postoperative anemia is associated with increased morbidity and mortality in patients undergoing surgery. Anemia is also a common feature during sepsis. Therefore, here, we aimed to investigate the safety and efficacy of intravenous iron isomaltoside 1000 $\left(\right.$ Monofer $^{\circledR}$ ) in patients undergoing elective urologic surgery and in those with urosepsis.

Materials and Methods: This multicenter study was conducted through the review of the medical records of patients with postoperative anemia undergoing elective urologic surgery or with urosepsis in a multicenter hospital. Patients received a single intravenous iron isomaltoside (IIM), and their hemoglobin $(\mathrm{Hb})$ level was evaluated before and after administration of IIM. Safety data included adverse effects and hypersensitivity reactions. In addition, the patients were divided into three groups (200 mg, $400 \mathrm{mg}$, and $600 \mathrm{mg}$ IIM) to compare $\mathrm{Hb}$ changes before and after the administration of IIM.

Results: The study analyzed 52 men and 30 women with a mean age of 67 years. There was a significant difference between pre-treatment $\mathrm{Hb}$ and post-treatment $\mathrm{Hb}$ according to the type of the surgery after administration $(\mathrm{p}=0.01)$ of IIM in patients with postoperative anemia, and the mean preoperative $\mathrm{Hb}$ before IIM administration was $8.5 \mathrm{~g} / \mathrm{dL}$ and that after IIM administration was $9.9 \mathrm{~g} / \mathrm{dL}$ ( $\mathrm{p}=0.006$ ) in patients with urosepsis. The mean preoperative $\mathrm{Hb}$ changed from $10 \mathrm{~g} /$ $\mathrm{dL}$ to $11 \mathrm{~g} / \mathrm{dL}$ after administration $(\mathrm{p}<0.001)$ of IIM in the whole cohort. There were no side effects due to the administration of intravenous IIM.

Conclusion: A single perioperative intravenous injection of IIM 1000 significantly increased the $\mathrm{Hb}$ level in patients with anemia who underwent urologic elective surgery. Moreover, this treatment can be considered to have potential clinical benefits for anemia caused by sepsis.
\end{abstract}

Keywords: anemia, iron, iron isomaltoside 1000, urosepsis

\section{Introduction}

Anemia is very common in patients with acute illness, including those in the intensive care unit. In 3534 ICU patients, Vincent et al observed mean hemoglobin (Hb) concentrations of $11.3 \mathrm{~g} / \mathrm{dL}$ at admission, with $29 \%$ of these patients having a concentration of less than $10 \mathrm{~g} / \mathrm{dL} .{ }^{1}$ Many factors are known to influence the $\mathrm{Hb}$ level in critically ill patients; some of the important factors among these are sepsis, overt or occult blood loss, decreased production of endogenous erythropoietin, and functional iron deficiency. ${ }^{2}$ 
Preoperative anemia was independently associated with increased morbidity and mortality in patients who underwent surgery. ${ }^{3,4}$ Untreated preoperative anemia and acute perioperative blood loss may increase surgical risk. Beattie et $\mathrm{al}^{5}$ reported that preoperative anemia was associated with a nearly five-fold increase in the odds of postoperative mortality in noncardiac surgery.

Sepsis is the culmination of complex interactions between the infecting microorganism and the host immune, inflammatory, and coagulation responses. ${ }^{6}$ Anemia is common in sepsis, in part because it is mediated by TNF- $\alpha$ and interleukin- $1 \beta$ and decreases the expression of the erythropoietin gene and protein. ${ }^{7}$ Sepsis due to urological problems, including obstructive uropathy and acute prostatitis, is common and fatal. The mortality ranges from $28 \%$ to $50 \%$ in patients with severe sepsis. Transfusion is worthwhile if needed at the emergency stage of sepsis; Rivers et al observed a marked decrease in mortality due to sepsis when transfusion was provided early. ${ }^{8}$

However, recent evidence has emerged to indicate that red blood cell transfusion may adversely impact patients who underwent surgery, causing higher mortality, increased risk of infection, and longer hospital and intensive care unit stays. $^{9,10}$

In addition, religious concerns, such as those posed by the Jehovah's Witnesses, may require a substitute for blood transfusion after elective surgery or sepsis. The use of erythropoiesis-stimulating agents and intravenous iron repletion have played a central role in the optimal correction of this anemia.

Therefore, here, we investigated the efficacy and safety of iron isomaltoside 1000 (Monofer $^{\mathbb{R}}$ ) in urologic sepsis and elective urologic surgery.

\section{Materials and Methods}

This study was conducted at two institutions (Hanyang University Seoul Hospital, Soonchunhyang University Seoul Hospital) in Korea from January to December 2017 and conducted in accordance with good clinical practice and the Declaration of Helsinki.

We performed our study after approving IRB from Hanyang University Hospital Institutional Review Board (IRB) (HY 2018-06-024-007). After approval was obtained with indication to have informed consent from IRB, written informed consent was obtained from all the patients. We reviewed the medical records of patients with postoperative anemia who were undergoing elective urologic surgery and patients with anemia due to sepsis.
We defined anemic condition as patients with $\mathrm{Hb} \leq 12.0 \mathrm{~g} /$ $\mathrm{dL}(7.45 \mathrm{mmol} / \mathrm{L})$ for women and $\mathrm{Hb} \leq 13.0 \mathrm{~g} / \mathrm{dL}(8.1$ $\mathrm{mmol} / \mathrm{L}$ ) for men, according to the WHO criteria. First, we excluded patients with iron overload or disturbances in utilization of iron (eg, hemochromatosis and hemosiderosis), s-ferritin $>800 \mathrm{ng} / \mathrm{mL}$, and diagnosed with inflammatory bowel disease such as Crohn's disease and ulcerative colitis. Also we excluded patients with known hypersensitivity to any excipients in the investigational drug products, history of multiple allergies, decompensated liver cirrhosis and hepatitis, alanine aminotransferase $>3$ times the normal upper value, acute infection, and rheumatoid arthritis with symptoms or signs of active joint inflammation and pregnant or nursing women. In addition, patients with preoperative anemia and those who received blood transfusions due to urosepsis were excluded.

Iron isomaltoside (IIM) was administrated when postoperative anemia was observed on the first day after urologic elective surgery, while in the group of anemic patients with urosepsis, the administration was done on the day of admission. We measured the change in $\mathrm{Hb}$ in 7 days for both groups.

Patients receiving single doses of isomaltoside 1000 over $15 \mathrm{~min}$ were divided into three groups: $200 \mathrm{mg}$, $400 \mathrm{mg}$, and $600 \mathrm{mg}$. We decided the dose of IIM according to the degree of $\mathrm{Hb}$ change level.

Any concomitant medication or treatment deemed necessary to provide adequate supportive care was allowed throughout the trial, except for erythropoiesis stimulating agents and any iron supplementation other than the investigational drug, as they would have influenced the outcome of the study.

\section{Objectives and Outcomes}

The primary efficacy objective of the study was to evaluate the change in $\mathrm{Hb}$ level after IV IIM administration in patients with anemia undergoing elective urologic surgery and patients with anemia and urosepsis. Except for patients with severe anemia who required blood transfusion those who underwent urologic elective surgery, IIM was administrated. Then we assessed the safety (adverse events, vital signs, electrocardiogram (ECG), and biochemistry parameters).

\section{Statistical Analyses}

We analyzed demographics, change in hemoglobin $(\mathrm{Hb})$ level, and $\mathrm{Hb}$ level according to the type of surgery using 
the Chi-squared test or Wilcoxon test, as appropriate. All statistical analyses were computed using SPSS (version 22.0 for Windows). All statistical tests were two-tailed, and the significance level was $<0.05$.

\section{Results}

\section{Patients}

In total, 82 patients were included in this study from January to December 2017 (Table 1). We classified the patients into two groups: patients with anemia that underwent urologic elective surgery $(n=66)$ and anemic patients with urosepsis $(n=16)$. Patients with urosepsis $(70.1$ years of age) were older than those undergoing urologic elective surgery (66.3 years of age). The patients were classified into three groups according to the dosage of iron isomaltoside 1000: $200 \mathrm{mg} / \mathrm{mL}(3.7 \%), 400 \mathrm{mg} / \mathrm{mL}(52.4 \%)$, and $600 \mathrm{mg} / \mathrm{mL}$ (43.9\%). Patient demographics and baseline characteristics are summarized in Table 1. Overall, more men $(63.4 \%)$ than women $(36.6 \%)$ were included in this study.

\section{Efficacy of Iron Isomaltoside 1000 (IIM)}

The primary efficacy analysis was the change in $\mathrm{Hb}$ concentration from baseline, following administration of IIM. We observed a significant difference between pretreatment $\mathrm{Hb}$ and post-treatment $\mathrm{Hb}$ according to the type of surgery after IIM administration $(p=0.01)$ in patients with postoperative anemia. The results of the $\mathrm{Hb}$ level change were measured by dividing patients into those who underwent stone surgery (including percutaneous nephrolithotomy) and those who underwent radical surgery and other endoscopic surgery. Seven days after surgery, $\mathrm{Hb}$ level had increased to an average of $11.4 \mathrm{~g} /$ $\mathrm{dL}$ from $9.5 \mathrm{~g} / \mathrm{dL}$ in the patients who underwent stone surgery, and also increased to an $11.0 \mathrm{~g} / \mathrm{dL}$ from $10.1 \mathrm{~g} / \mathrm{dL}$ in the patients who underwent other surgery. We also found a significant difference between stone surgery (including percutaneous nephrolithotomy) and other types of urologic surgery $(\mathrm{p}=0.009)$ (Table 2$)$. The mean preoperative $\mathrm{Hb}$ before IIM administration was $8.5 \mathrm{~g} / \mathrm{dL}$, and it was $9.9 \mathrm{~g} / \mathrm{dL}$ after IIM administration $(\mathrm{p}=0.006)$ in patients with urosepsis (Table 3). Mean preoperative $\mathrm{Hb}$ changed from $10 \mathrm{~g} / \mathrm{dL}$ to $11 \mathrm{~g} / \mathrm{dL}$ after administration $(p<0.001)$ in the whole cohort.

The $\mathrm{Hb}$ level change differed according to the type of surgery in this cohort (Figure 1), and the pre-treatment $\mathrm{Hb}$ level and post-treatment $\mathrm{Hb}$ level were different for each surgery type (Figure 2). The pre-treatment $\mathrm{Hb}$ level and post-treatment $\mathrm{Hb}$ level in patients with urosepsis were also different (Figure 3).

\section{Safety}

Among the 82 patients available for safety analysis in the present study, no adverse drug reactions were reported to be related to the IIM. The hematological and biochemistry parameters and vital signs were checked at each trial visit, and no cases of hypophosphatemia (defined as a phosphate level $<2 \mathrm{mg} / \mathrm{dL}$ ) were observed.

\section{Discussion}

This study is, to the best of our knowledge, the first cohort study to investigate the effects of intravenous iron

Table I Characteristics of Patients According to Group

\begin{tabular}{|c|c|c|c|}
\hline Variables & Urologic Elective Surgery* & Urosepsis & Total \\
\hline Patients, $\mathrm{n}$ & 66 & 16 & 82 \\
\hline Age, yr.(SD) & $66.3(11.3)$ & $70.1(15.2)$ & $67.0(12.1)$ \\
\hline \multicolumn{4}{|l|}{ Gender, n(\%) } \\
\hline Male & $44(66.7 \%)$ & $6(37.5 \%)$ & $52(63.4 \%)$ \\
\hline Female & $22(33.3 \%)$ & $10(62.5 \%)$ & $30(36.6 \%)$ \\
\hline Weight, kg(SD) & $62.9(8.6)$ & $60.9(8.3)$ & $62.5(8.6)$ \\
\hline \multicolumn{4}{|l|}{ Iron isomaltoside 1000 dosage, $\mathrm{mg}, \mathrm{n}(\%)$} \\
\hline 200 & $3(4.5 \%)$ & $0(0 \%)$ & $3(3.7 \%)$ \\
\hline 400 & $31(47 \%)$ & $12(75 \%)$ & $43(52.4 \%)$ \\
\hline 600 & $32(48.5 \%)$ & $4(25 \%)$ & $36(43.9 \%)$ \\
\hline Follow up period, day(SD) & I2.8(9.4) & $8.6(3.8)$ & $12.710(10.9)$ \\
\hline Pre-treatment hemoglobin, mmol//(SD) & $10.2(1.5)$ & $9.1(1.2)$ & $10(1.5)$ \\
\hline
\end{tabular}

Notes: Urologic elective surgery*: Radical surgery (cancer), Stone surgery (endoscopic, PNL), Other endoscopic surgery. 
Table 2 Outcomes of Elective Surgery Type

\begin{tabular}{|l|l|l|l|l|l|}
\hline Type of Surgery & $\mathbf{n}$ & Pre-Treatment Hb & Post-Treatment Hb & Hb Change & p-value \\
\hline Sub-type & & & & $0.8(1.2)$ \\
$\quad$ Radical surgery & 30 & $10.3(1.6)$ & $11.2(1.4)$ & $1.9(0.8)$ \\
Stone surgery (endoscopic) & 12 & $9.4(1.3)$ & $11.3(1.3)$ & $1.8(0.7)$ \\
Stone surgery (PNL) & 5 & $9.96(1.8)$ & $11.8(1.5)$ & 1 \\
Stone surgery (Etc.) & 1 & 9 & 10 & $0.5(1.3)$ \\
Endoscopic surgery & 18 & $10.8(1.2)$ & $11.3(1.2)$ & \\
\hline Stone vs other & & & $11.4(1.3)$ & $1.9(0.7)$ \\
$\quad$ Stone surgery & 18 & $9.5(1.4)$ & $11(1.3)$ & $0.9(1.2)$ \\
$\quad$ Other surgery & 48 & $10.1(1.6)$ & & 0.009 \\
\hline
\end{tabular}

Note: $\mathrm{p}<0.05$ is considered to be statistically significant.

Table 3 Comparison of $\mathrm{Hb}$ Change Before and After Treatment with Iron Isomaltoside 1000

\begin{tabular}{|c|c|c|c|c|c|}
\hline Variables & $\mathbf{n}$ & Pre-Treatment $\mathrm{Hb}$ & Post-Treatment $\mathrm{Hb}$ & Hb Change & p-value \\
\hline Total & 82 & $10.0(1.5)$ & II.0(I.3) & $\mathrm{I}(\mathrm{I} .2)$ & $<0.001$ \\
\hline Urosepsis & 9 & $8.5(0.4)$ & $9.9(0.4)$ & I.4(0.3) & 0.006 \\
\hline \multicolumn{6}{|l|}{ Dosage } \\
\hline 200 & 3 & $9.4(1)$ & $9.9(0.6)$ & $0.5(I)$ & $<0.001$ \\
\hline 400 & 43 & $9.1(1.1)$ & $10.7(1.3)$ & $1.6(1)$ & \\
\hline 600 & 36 & II.I(I.3) & $11.5(1.2)$ & $0.5(1.3)$ & \\
\hline \multicolumn{6}{|l|}{ Initial $\mathrm{Hb}$} \\
\hline Under 10 & 53 & $9(0.9)$ & $10.5(I .1)$ & $1.5(0.9)$ & 0.001 \\
\hline Over II & 29 & $11.7(0.7)$ & $12(1.1)$ & $0.3(1.1)$ & \\
\hline
\end{tabular}

Note: $p<0.05$ is considered to be statistically significant.

administration in place of allogenic blood transfusion in patients with postoperative anemia in the field of urologic surgery. The etiology of anemia is diverse and includes blood loss, decreased RBC production owing to functional iron deficiency, and altered erythropoiesis in critically ill patients. In addition, perioperative anemia, which occurs in $33 \%$ to $50 \%$ of surgical patients, is one of the major predictive factors for allogenic blood transfusion (ABT) in surgeries with moderate to high perioperative blood loss and it induces postoperative anemia and aggravates existing anemia. ${ }^{11}$

ABT carries increased risks for transmission of infectious diseases, postoperative nosocomial infection and has been clearly demonstrated to be associated with adverse outcomes related to postoperative acute kidney injury, neurological complications and postoperative atrial fibrillation after cardiac surgery. ${ }^{12}$ Despite efforts to reduce $\mathrm{ABT}$, transfusion requirements still remain high. In this regard, a discussion on patient blood management (PBM) programs aim at identifying patients at risk for transfusions has been conducted in Europe. ${ }^{13}$ PBM programs are based on multimodal approach including early preoperative recognition and treatment of anemic patients, surgical efforts to minimize blood loss. From this point of view, preoperative optimization of anemia seems to be a key aspect of PBM.

Iron deficiency is common, either owing to the depletion of whole-body iron stores or because of the restricted availability of iron for erythrogenesis (functional iron deficiency). Thus, iron therapy is commonly used to restore the iron reserve to prevent anemia after bleeding. Iron plays an essential role in erythropoiesis and hemoglobin synthesis. ${ }^{14}$ Therefore, here, we tried to investigate the effect of the preoperative administration of intravenous iron isomaltoside 1000 (Monofer $^{\circledR}$ ) in patients undergoing elective urologic surgery. In our study, a significant elevation in $\mathrm{Hb}$ was observed without blood transfusion in endoscopic stone surgery and percutaneous nephrolithotomy (PNL), which can cause postoperative anemia or bleeding. 


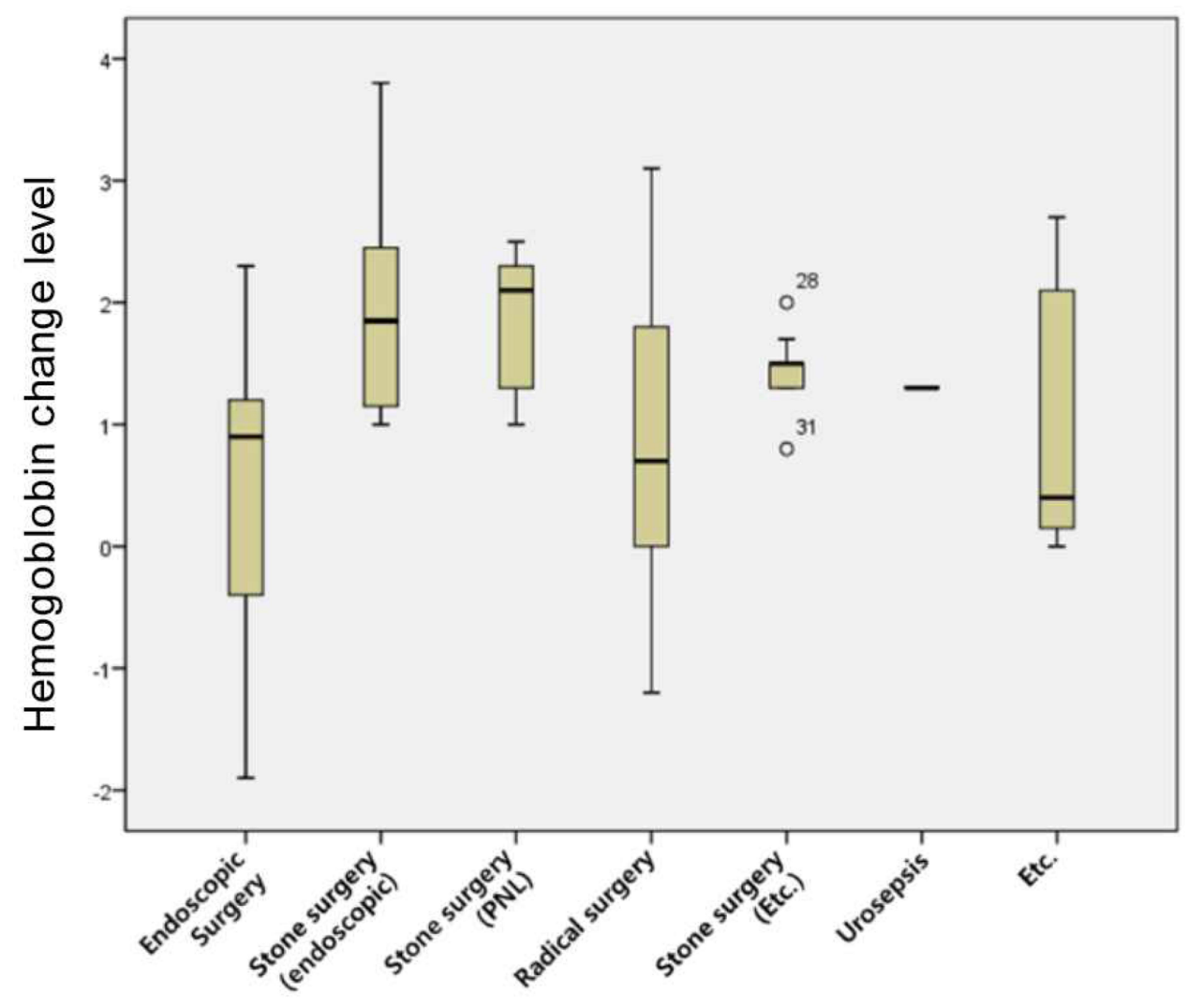

\section{Elective Urologic surgery, Urosepsis and Etc}

Figure I The change of hemoglobin level according to the type of surgery.

The new IV iron supplement, iron isomaltoside 1000 (IIM), is composed of iron and chemically modified isomalto-oligosaccharides that have a mean molecular weight of $1000 \mathrm{Da}$ and consist predominantly of 3-5 glucose units. In contrast to dextran polysaccharides present in iron dextran, isomaltoside is a linear and unbranched molecule with a theoretically reduced anaphylactogenic potential. ${ }^{15}$ Physiochemically, the strong binding of iron within the IIM formulation enables a controlled and slow release of bioavailable iron to the iron-binding proteins, with only a low risk of free iron toxicity. ${ }^{16}$ This allows the rapid administration of high single doses of IIM. Several studies employing IIM have shown it to be well tolerated and to improve iron-related parameters in patients with various conditions, including patients with CKD receiving dialysis, ${ }^{17}$ patients with chronic heart failure, patients with inflammatory bowel disease, ${ }^{18,19}$ and patients undergoing cardiac surgery,${ }^{20}$ major orthopedic surgery, ${ }^{11}$ or major abdominal surgery. ${ }^{21}$ To date, clinical trials of IIM have demonstrated a good efficacy and a good safety profile, and systemic reviews and meta-analysis of randomized clinical trials comparing intravenous iron to other comparators have indicated that all currently available intravenous iron preparations are safe. ${ }^{22,23}$

Perioperative anemia is common among patients scheduled to undergo elective surgery and it is also a predictor of blood transfusion. The prevalence of perioperative anemia is reported to range from $5 \%$ to $75 \%$ of electively scheduled patients. ${ }^{24,25}$ In our study, the average $\mathrm{Hb}$ level of 66 patients who were scheduled for elective surgery was $10.2 \mathrm{~g} / \mathrm{dL}$, which is quite low according to the definition provided by the World Health Organization. Van Straten et $\mathrm{al}^{4}$ reported that a lower preoperative $\mathrm{Hb}$ level is an independent predictor of late mortality in patients undergoing coronary artery bypass grafting, whereas anemia is a risk factor for early and late mortality. Iron-deficiency anemia is the most common form of anemia and may be associated with other hematologic deficiencies, particularly among the elderly population; it compromises patients' ability to recover $\mathrm{Hb}$ after surgery. ${ }^{26}$ Based on previous studies and our experiences, we expect intravenous iron administration to be able to reduce the incidence of postoperative infections associated with blood transfusion, reduce the 


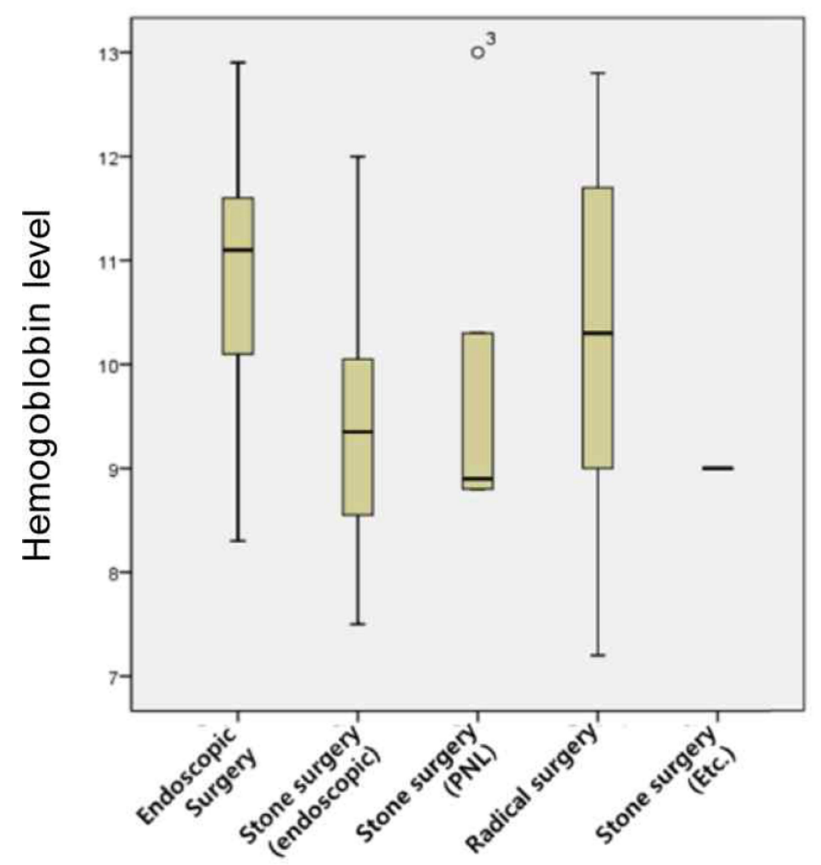

Type of Urologic surgery

A Pre-treatment

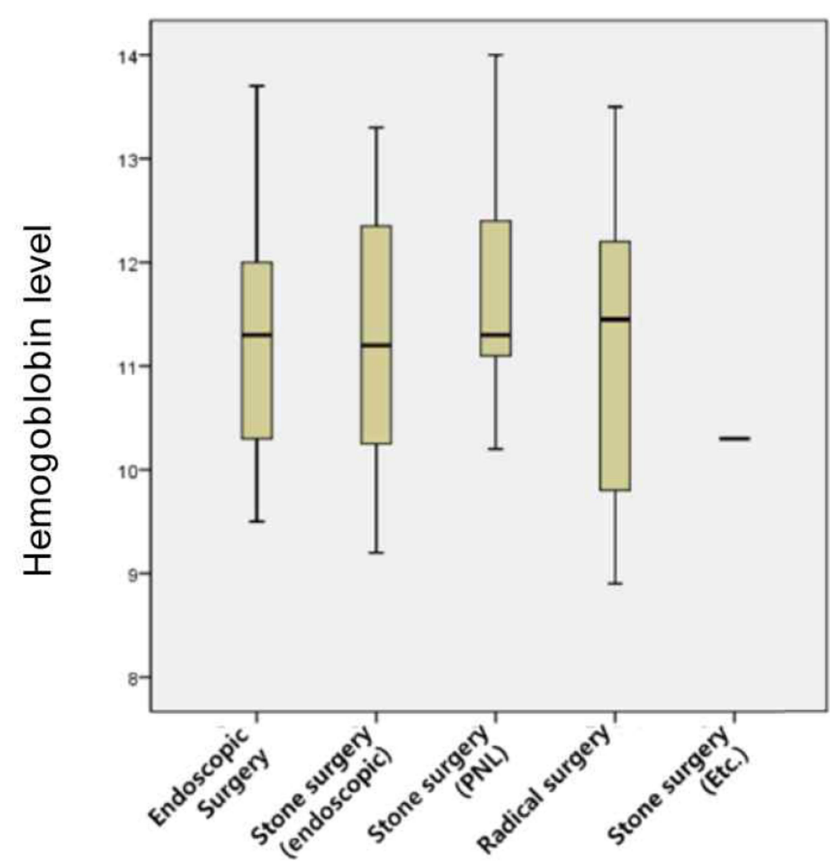

Type of Urologic surgery

B Post-treatment

Figure 2 The differences of hemoglobin level for each surgery type. (A) Pre-treatment (B) Post-treatment.

length of hospital stay, and facilitate better recovery and outcome.

Another notable result of our study was that intravenous iron administration caused a statistically significant elevation of the $\mathrm{Hb}$ level (from $8.5 \mathrm{~g} / \mathrm{dL}$ to $9.9 \mathrm{~g} / \mathrm{dL}$ ) in patients with

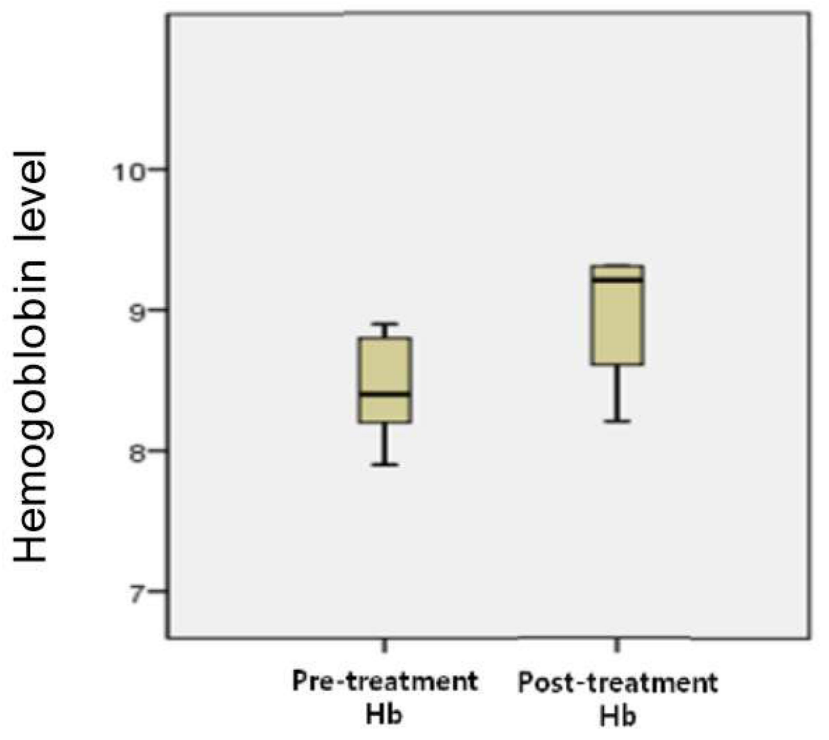

Figure 3 The pre-treatment $\mathrm{Hb}$ level and post-treatment $\mathrm{Hb}$ level in patients with urosepsis. urosepsis. Consensus guidelines for the management of sepsis have been published. ${ }^{27}$ Early in the course of sepsis, the cornerstone of emergency management of sepsis is early, goaldirected therapy plus administration of lung protective ventilation broad-spectrum antibiotics. ${ }^{8,28}$ Similar to the management of patients with sepsis, the guideline for patients with urosepsis recommends antibiotic treatment as soon as possible after diagnosis, but only after blood and urine cultures have been obtained (recommendation grade $\mathrm{B}$, evidence level Ic). ${ }^{29}$ According to the concept of early goal-directed therapy, hemodynamic stabilization promotes the delivery of an adequate oxygen supply to the tissues. Therefore, as soon as the diagnosis of urosepsis is suspected, the intravenous administration of isotonic crystalloid solution should be started, and blood products should be administered to target a hemoglobin level of 7-9 g/dL. Anemia is common in sepsis, and erythropoietin requires between days to weeks to induce red blood cell production; thus, it may not be effective. ${ }^{7}$ To date, the criteria for which blood products should be used to correct anemia with supportive treatment in urosepsis are unclear and lack supporting evidence. In our study, 16 patients with urosepsis showed a significant increase in $\mathrm{Hb}$ level (from $8.5 \mathrm{~g} / \mathrm{dL}$ to 9.9 $\mathrm{g} / \mathrm{dL}$ ) after the administration of IIM. Our study also showed that the degree of elevation of the $\mathrm{Hb}$ level was significantly 
greater in the group with initial $\mathrm{Hb} \leq 10 \mathrm{~g} / \mathrm{dL}$ compared to that in the group with initial $\mathrm{Hb} \geq 11 \mathrm{~g} / \mathrm{dL}$ when comparing the effects of intravenous IIM. Based on these findings, IIM may be an alternative to allogenic blood transfusion, with a reduced incidence of adverse effects due to blood transfusion, which may increase mortality.

To date, there are no clinical guidelines to support the use of prophylactic intravenous iron before major elective surgery. Therefore, we searched the literature in MEDLINE (January 1, 1990, through December 31, 2017) that examined intravenous iron therapy in patients scheduled to undergo elective surgery, except for patients with iron-deficiency anemia, inflammatory bowel disease, and chronic kidney disease. We selected and summarized five studies that were well-designed. One paper described treatment with IIM and four papers detailed treatment with iron sucrose (Table 4). Owing to the differences in the type, timing, and dosage of the intravenous iron supplement used prior to surgery, the results of the $\mathrm{Hb}$ level and transfusion requirements were statistically different. When comparing our study with the PROTECT trial, which evaluated the effect of perioperative IV IIM in patients without anemia undergoing elective or subacute coronary artery bypass graft or valve replacement, we found that the $\mathrm{Hb}$ level had significantly increased, and fewer patients were anemic in the IV IIM-treated group in both studies. ${ }^{20}$

This trial was an exploratory and retrospective study with the limitation of a small sample size of the patients undergoing elective urologic surgery. And the limitation of this study is that there was no data on iron-related parameters (transferrin saturation, ferritin, reticulocytes) as a retrospective study to find out the effects of IIM as an alternative to blood transfusion in patients who underwent urologic surgery with postoperative anemia. In this cohort, there was no control group receiving either placebo or comparing result about transfusion requirement. We only compared and reported the treatment before and after at anemic status. Designed as a retrospective study, there is a limitation that each group could be heterogenous. The novelties of this study are the feasibility of Intravenous IIM in patients with anemia after elective urologic surgery and the efficacy of Intravenous IIM in patients with anemia due to urosepsis.

Table 4 Summary of Studies About Intravenous Iron Preparations for Patients Undergoing Elective Surgery

\begin{tabular}{|c|c|c|c|}
\hline Study & Population & Interventions & Findings \\
\hline $\begin{array}{l}\text { Johansson et al } \\
\text { (the } \\
\text { PROTECT } \\
\text { trial, } \\
\text { Denmark) }\end{array}$ & $\begin{array}{l}60 \text { non-anemic pts } \\
\text { undergoing elective or } \\
\text { subacute CABG, valve } \\
\text { replacement }\end{array}$ & $\begin{array}{l}\text { Randomized, double-blind placebo-controlled } \\
\text { trial: iron isomaltoside } 1000 \text { as an IV infusionof } \\
1000 \text { mg (treatment group A) or placebo }(0.9 \% \\
\text { saline) (treatment group B) }\end{array}$ & $\begin{array}{l}\text { One month after surgery, Hb concentration } \\
\text { had increased to an average of I } 2.6 \mathrm{~g} / \mathrm{dl} \text { vs II.8 } \\
\mathrm{g} / \mathrm{dl}(\mathrm{p}=000 \mathrm{I}) \text { and significantly more patients } \\
\text { were non-anaemic in the IV iron isomaltoside } \\
\text { I000-treated group compared to the placebo } \\
\text { group }(38.5 \% \text { vs. } 8.0 \% ; \mathrm{p}=0.019) \text {. }\end{array}$ \\
\hline $\begin{array}{l}\text { Theusinger } \\
\text { et al } \\
\text { (Switzerland) }^{26}\end{array}$ & $\begin{array}{l}20 \text { pts with iron deficiency } \\
\text { anemia undergoing knee or } \\
\text { hip arthroplasty or back } \\
\text { surgery }\end{array}$ & $\begin{array}{l}\text { Prospective study: } 900 \mathrm{mg} \text { IV iron sucrose over } \\
\text { I0 days starting } 4 \text { weeks before surgery }\end{array}$ & $\begin{array}{l}\mathrm{Hb} \text { increased significantly }(\mathrm{p}<0.00 \mathrm{I}) \text {, the mean } \\
\text { maximum increase was } 0.2-2.2 \mathrm{~g} / \mathrm{dl} \text {. The } \\
\text { maximum increase of hemoglobin was } \\
\text { observed } 2 \text { weeks after the start of IV iron } \\
\text { treatment. }\end{array}$ \\
\hline $\begin{array}{l}\text { Edwards TJ. } \\
\text { et al (UK) })^{30}\end{array}$ & $\begin{array}{l}62 \text { pts undergoing bowel } \\
\text { resection for suspected } \\
\text { colorectal cancer }\end{array}$ & $\begin{array}{l}\text { Randomized prospective blinded placebo- } \\
\text { controlled trial: } 600 \mathrm{mg} \text { iron sucrose or } \\
\text { placebo was given intravenously in two divided } \\
\text { doses }\end{array}$ & $\begin{array}{l}\text { No difference was demonstrated between } \\
\text { treatment groups (iron sucrose, } 34 \text { patients; } \\
\text { placebo, 26) for any of the primary outcome } \\
\text { measure }\end{array}$ \\
\hline $\begin{array}{l}\text { Garrido- } \\
\text { Martin P. et al } \\
\text { (Spain) }^{31}\end{array}$ & $\begin{array}{l}\text { I } 59 \text { pts undergoing elective } \\
\text { cardiac surgery under } \\
\text { extracorporeal circulation }\end{array}$ & $\begin{array}{l}\text { Double-blind, randomized, placebo-controlled } \\
\text { trial (Group I: treated with } 300 \mathrm{mg} \text { of IV iron } \\
\text { sucrose, group 2: treated with oral ferrous } \\
\text { fumarate, group 3: oral and IV placebo) }\end{array}$ & $\begin{array}{l}\text { The use of IV or oral iron supplementation } \\
\text { proved ineffective in correcting anaemia after } \\
\text { cardiopulmonary bypass and did not reduce } \\
\text { blood transfusion requirements }\end{array}$ \\
\hline $\begin{array}{l}\text { Serrano- } \\
\text { Trenas JA et al } \\
\text { (Spain) }\end{array}$ & $\begin{array}{l}200 \text { pts undergoing hip } \\
\text { fracture surgery }\end{array}$ & $\begin{array}{l}\text { Prospective, randomized study: divided into } \\
\text { two groups, standard treatment or IV iron } \\
\text { sucrose }(600 \mathrm{mg})\end{array}$ & $\begin{array}{l}\text { Transfusion requirements in patients with } \\
\text { intracapsular fracture or baseline } \mathrm{Hb} \text { level of } 12 \\
\mathrm{~g} / \mathrm{dL} \text { or more appear to be reduced by IV iron } \\
\text { sucrose therapy, but there was no difference in } \\
\text { morbidity, mortality, or length of hospital stay. }\end{array}$ \\
\hline
\end{tabular}


Hence, we are planning additional clinical studies employing a large, randomized, controlled, prospective trial to allow further evaluation of the differences in effect according to iron status (serum iron, ferritin, and transferrin saturation index) for the treatment of anemia in clinical settings.

\section{Conclusion}

This study has demonstrated that IIM can be used safely and effectively to prevent anemia after elective urologic surgery and reduce the need for blood transfusion. The reviewed data in patients who underwent urologic elective surgery $(\mathrm{n}=66)$ and patients with anemia and urosepsis $(\mathrm{n}=16)$ showed adequate efficacy and a good safety profile of IIM. The results also showed that the hemopoietic response was evident in urosepsis. The safety profile of IIM is favorable. Therefore, we expect that the administration of IIM is attractive not only for patients with anemia that are undergoing urologic surgery, but also for patients with anemia due to sepsis.

\section{Abbreviations}

IIM, iron isomaltoside; $\mathrm{Hb}$, hemoglobin; ICU, intensive care unit; ABT, allogenic blood transfusion; PBM, patient blood management; PNL, percutaneous nephrolithotomy; CKD, chronic kidney disease.

\section{Acknowledgment}

This article was funded by Pharmbio Inc. This study was performed statistical analysis by Inha Yoon, Ji Ye Han.

\section{Disclosure}

The authors report no conflicts of interest for this work.

\section{References}

1. Vincent JL, Baron JF, Reinhart K, et al. Anemia and blood transfusion in critically ill patients. JAMA. 2002;288(12):1499-1507.

2. Viljoen M, Coetzee IH, Roux LJ, et al. Anemia in surgical intensive care patients. Haematologica. 1994;79(1):19-24.

3. Karkouti K, Wijeysundera DN, Beattie WS. the Reducing Bleeding in Cardiac surgery (RBC) investigators. Risk associated with preoperative anemia in cardiac surgery: a multicentre cohort study. Circulation. 2008;117(4):478-484. doi:10.1161/CIRCULATIONAHA.107.718353

4. Van Straten AHM, Hamad MA, van Zundert AJ, et al. Preoperative Hemoglobin level as a predictor of survival after coronary artery bypass grafting. Circulation. 2009;120(2):118-125. doi:10.1161/ CIRCULATIONAHA.109.854216

5. Beattie WS, Karkouti K, Wijeysundera DN, et al. Risk associated with preoperative anemia in noncardiac surgery: a single-center cohort study. Anesthesiology. 2009;110:574-581.

6. Hotchkiss RS, Karl IE. The pathophysiology and treatment of sepsis. N Engl J Med. 2003;348(2):138-150. doi:10.1056/NEJMra021333

7. Jelkmann W. Proinflammatory cytokines lowering erythropoietin production. J Interferon Cytokine Res. 1998;18(8):555-559. doi:10.1089/jir.1998.18.555
8. Rivers E, Nguyen B, Havstad S, et al. Early goal-directed therapy in the treatment of severe sepsis and septic shock. $N$ Engl J Med. 2001;345(19):1368-1377. doi:10.1056/NEJMoa010307

9. Dunne JR, Malone D, Tracy JK, et al. Perioperative anemia: an independent risk factor for infection, mortality, and resource utilization in surgery. J Surg Res. 2002;102(2):237-244. doi:10.1006/ jsre.2001.6330

10. Bernard AC, Davenport DL, Chang PK, et al. Intraoperative transfusion of $1 \mathrm{U}$ to $2 \mathrm{U}$ packed red blood cells is associated with increased 30-day mortality, surgical-site infection, pneumonia, and sepsis in general surgery patients. J Am Coll Surg. 2009;208(5):931-937. doi:10.1016/j.jamcollsurg.2008.11.019

11. Munoz M, Gomez-Ramirez S, Cuenca J, et al. Very-short-term perioperative intravenous iron administration and postoperative outcome in major orthopedic surgery: a pooled analysis of observational data from 2547 patients. Transfusion. 2014;54(2):289-299.

12. Koch CG, Li L, Van Wagoner DR, et al. Red cell transfusion is associated with an increased risk for postoperative atrial fibrillation. Ann Thorac Surg. 2006;82(5):1747-1756. doi:10.1016/j.athoracsur.2006.05.045

13. Theusinger OM, Felix C, Spahn DR. Strategies to reduce the use of blood products: a European perspective. Curr Opin Anaesthesiol. 2012;25(1):59-65. doi:10.1097/ACO.0b013e32834dec98

14. Silverberg DS, Iaina A, Peer G, et al. Intravenous iron supplementation for the treatment of the anemia of moderate to severe chronic renal failure patients not receiving dialysis. Am J Kidney Dis. 1996;27(2):234-238. doi:10.1016/S0272-6386(96)90546-6

15. Altman LC, Petersen PE. Successful prevention of an anaphylactoid reaction to iron dextran. Ann Intern Med. 1988;109:346-347. doi:10.7326/0003-4819-109-4-346

16. Jahn MR, Andreasen HB, F€utterer S, et al. A comparative study of the physicochemical properties of iron isomaltoside 1000 (Monofer), a new intravenous iron preparation and its clinical implications. Eur J Pharm Biopharm. 2011;78:480-491. doi:10.1016/j.ejpb.2011.03.016

17. Bhandari S, Kalra PA, Kothari J, et al. A randomized, open-label trial of iron isomaltoside 1000 (MonoferVR) compared with iron sucrose (VenoferVR) as maintenance therapy in haemodialysis patients. Nephrol Dial Transplant. 2015;30:1577-1589. doi:10.1093/ndt/ gfv096

18. Reinisch W, Altorjay I, Zsigmond F, et al. A 1-year trial of repeated high-dose intravenous iron isomaltoside 1000 to maintain stable hemoglobin levels in inflammatory bowel disease. Scand $J$ Gastroenterol. 2015;50(10):1226-1233. doi:10.3109/00365521. 2015.1031168

19. Dahlerup J, Lindgren S. High dose intravenous iron isomaltoside 1000 in patients with inflammatory bowel disease - the PROMISE trial. Poster presented at 10th Congress of the European Crohn's and Colitis Organisation (ECCO), February 8-21; 2015; Barcelona, Spain.

20. Johansson PI, Rasmussen AS, Thomsen LL. Intravenous iron isomaltoside 1000 (MonoferVR) reduces postoperative anaemia in preoperatively non-anaemic patients undergoing elective or subacute coronary artery bypass graft, valve replacement or a combination thereof: a randomized double-blind placebo-controlled clinical trial (the PROTECT trial). Vox Sang. 2015;109:257-266.

21. Froessler B, Palm P, Weber I, et al. The important role for intravenous iron in perioperative patient blood management in major abdominal surgery: a randomized controlled trial. Ann Surg. 2016;264(1):41-46. doi:10.1097/SLA.0000000000001646

22. Avni T, Bieber A, Grossman A, et al. The safety of intravenous iron preparations: systematic review and meta-analysis. Mayo Clin Proc. 2015;90(1):12-23. doi:10.1016/j.mayocp.2014.10.007

23. Rognoni C, Venturini S, Meregaglia M, et al. Efficacy and safety of ferric carboxymaltose and other formulations in iron-deficient patients: a systematic review and network meta-analysis of randomised controlled trials. Clin Drug Investig. 2016;36(3):177-194. doi:10.1007/s40261-015-0361-z 
24. Goodnough LT, Shander A, Spivak JL, et al. Detection, evaluation, and management of anemia in the elective surgical patient. Anesth Analg. 2005;101:1858-1861. doi:10.1213/01.ANE.0000184124.29397.EB

25. Shander A, Knight K, Thurer R, et al. Prevalence and outcomes of anemia in surgery: a systematic review of the literature. Am J Med. 2004;116(Suppl 7A):58S-69S. doi:10.1016/j.amjmed.2003.12.013

26. Theusinger OM, Leyvraz P-F, Schanz U, et al. Treatment of iron deficiency anemia in orthopedic surgery with intravenous iron: efficacy and limits: a prospective study. Anesthesiology. 2007;107 (6):923-927. doi:10.1097/01.anes.0000291441.10704.82

27. Dellinger RP, Carlet JM, Masur H, et al. Surviving Sepsis Campaign guidelines for management of severe sepsis and septic shock. Crit Care Med. 2004;32(3):858-873. doi:10.1097/01.CCM.0000117317.18092. E4

28. Ibrahim EH, Sherman G, Ward S, et al. The influence of inadequate antimicrobial treatment of bloodstream infections on patient outcomes in the ICU setting. Chest. 2000;118(1):146-155. doi:10. 1378/chest.118.1.146
29. Dreger NM, Degener S, Ahmad-Nejad P, et al. Urosepsis-etiology, diagnosis, and treatment. Dtsch Arztebl Int. 2015;112:837-847.

30. Edwards TJ, Noble EJ, Durran A, et al. Randomized clinical trial of preoperative intravenous iron sucrose to reduce blood transfusion in anaemic patients after colorectal cancer surgery. Br J Surg. 2009;96 (10):1122-1128. doi:10.1002/bjs.6688

31. Garrido-Martín P, Nassar-Mansur MI, de la Llana-ducrós R, et al. The effect of intravenous and oral iron administration on perioperative anaemia and transfusion requirements in patients undergoing elective cardiac surgery: a randomized clinical trial. Interact Cardiovasc Thorac Surg. 2012;15(6):1013-1018. doi:10.1093/icvts/ ivs344

32. Serrano-Trenas JA, Ugalde PF, Cabello LM, et al. Role of perioperative intravenous iron therapy in elderly hip fracture patients: a single-center randomized controlled trial. Transfusion. 2011;51 (1):97-104. doi:10.1111/j.1537-2995.2010.02769.x

\section{Publish your work in this journal}

Drug Design, Development and Therapy is an international, peerreviewed open-access journal that spans the spectrum of drug design and development through to clinical applications. Clinical outcomes, patient safety, and programs for the development and effective, safe, and sustained use of medicines are a feature of the journal, which has also been accepted for indexing on PubMed Central. The manuscript management system is completely online and includes a very quick and fair peer-review system, which is all easy to use. Visit http://www. dovepress.com/testimonials.php to read real quotes from published authors. 